\title{
MIST-NETTING OF MIGRATING BEE-EATERS POSITIVELY INFLUENCES HONEY BEE COLONY PERFORMANCE
}

\author{
Aleksandra Łangowska1* \\ Reuven Yosef ${ }^{2}$ \\ Piotr Skórka ${ }^{3}$ \\ Piotr Tryjanowski ${ }^{1}$ \\ 'Poznań University of Life Sciences, Institute of Zoology, Poland \\ 2International Birding \& Research Centre in Eilat, Ben Gurion University - Eilat \\ Campus, Eilat, Israel \\ ${ }^{3}$ Institute of Nature Conservation, Polish Academy of Sciences, Kraków, Poland \\ *corresponding author: alango@up.poznan.pl \\ Received: 16 November 2017; accepted: 1 December 2017
}

Abstract

Bee-eaters (Meropidae) are considered agricultural pests and their presence provokes conflicts with beekeepers and farmers who rely on the pollination services of honey bees. This problem is often deal with through the mass killing of the birds, even though the quantitative evidence on the impact of bee-eaters on honey bee colonies is scarce. The current paper reports the performance of honey bee colonies protected with mist nets from migrating flocks of European bee-eaters Merops apiaster in Israel. In the study the weight gains of bee hives surrounded by mist nets were 6.44 times higher than that of unprotected hives (26.4 kg vs. $4.1 \mathrm{~kg}$ ). The results confirmed that bee-eaters locally pose a problem to apiaries and potentially to the crops that require pollination. Mistnetting appeared to be an effective mitigation method for alleviating conflicts between beekeepers and bee-eaters. However, the study also showed that bees were able to differentiate between their main predator and other avian species trapped in mist nets and stung only bee-eaters. Moreover, the bees were targeting the most vulnerable body parts of birds which resulted in some bird fatalities. Therefore, due to accidental mortality of birds, mist-netting is recommended only on the migratory routes in cases when bee hives cannot be moved to other areas.

Keywords: honey production, migration, pollination, predatory pressure, vertebrate pests

\section{INTRODUCTION}

Pollination is one of the most recognized ecosystem services, and bees including honey bee Apis mellifera L. are the most valued pollinators of agricultural crops (Potts et al., 2010). Recent research on the decline of bees has focused on the risks associated with environmental changes and/or diseases (Goulson et al., 2015), but from an evolutionary perspective, at least in the past and locally at present, predation is one of the most serious and immediate threats (Dukas, 2001).

From the diverse group of honey bee predators, bee-eaters Merops spp. (De Jong, 1990), strongly determine the performance of bee colonies across their geographical range (Fry,
1983). Several studies have demonstrated that Hymenopterans (mostly honey bees) are the most important prey in the diet of the European bee-eater (reviewed by Cramp \& Simmons, 1985) and bees may constitute up to $69.4-82.0 \%$ of its diet (Martínez, 1984). The European bee-eater mainly breeds in Southern Europe and in autumn migrates south to Africa. However, its breeding distribution covers much of Europe and Africa. Bee-eaters migrate in large flocks, up to thousands of individuals and collect mostly flying insects in open and semi-open areas, including farmland and in the vicinity of human settlements (Fry \& Fry, 2010).

The recorded prevalence of bees in the diet of bee-eaters (including other species than European bee-eater) led to their perception as a 
common honey bee pest. In Israel, the European bee-eater is listed as one of 61 vertebrate species of economic significance and also as one that inflicts agricultural damage and is known to influence Cucurbitaceae pollination (Moran \& Keidar, 1993). Bee-eaters are recognized as honey bee pests throughout the Middle East (Iran: Esmali, 1974; Saudi Arabia: El - Sarrag, 1993; Ali, 2012; Egypt: Hussein et al., 2001; Iraq: Glaiim, 2014; Jordan, also M. orientalis. Al-Ghzawi, Zaitoun, \& Shannag, 2009), East Africa (Ethiopia: Yirga, 2012; Somalia, including M. revoilii. Hussein, 2000) and Asia (including $M$. orientalis in Nepal: Ranabhat \& Tamrakar, 2009). Bee-eaters are protected by law in many countries but there are a few official accounts of mass killings. Robinson (1981) reported that a beekeeper in the Jordan Valley shot bee-eaters 'at every opportunity', and Tucker \& Heath (1994), Fry \& Fry (2010) and Gyurácz et al. (2013) suggest the problem of a mass extermination by hunters and poachers.

The European bee-eater breeds or passes through European countries and is considered as an apiary pest and so potentially threatened due to illegal extermination (Gyurácz et al., 2013; BirdLife International, 2016; Brochet et al., 2016). This problem is neglected by governmental agencies and services and only a few studies have tried to deal with it. Moreover, Dhindsa \& Saini (1994) stated that in India there was insufficient data to claim that bee-eaters seriously affected apiculture. Most papers report honey losses based on reduced bee activity observations and potential bee losses in the apiaries based on the food requirements of bee-eaters (e.g. Alfallah, Alfituri, \& Hmuda, 2010; Glaiim, 2014). We are aware of only one study that directly quantified honey loss in the Andalusian region of Spain (Chirosa \& Orantes, 2003) where European bee-eater also breed.

The aim of the present study was to clarify the pest status of European bee-eater through the estimation of the effect of migrating birds on apiaries located in the Arava Valley, Israel. Modern farms in Arava are an important part of the Israeli food production market. The sophisticated agricultural techniques applied in the area allow for an all-year growing season. For crop pollination farmers widely use honey bees which are delivered in boxed hives by apiarists. However, southern Israel is also an important and well recognized migratory flyway of many Palearctic birds (e.g. Yosef \& Markovets, 2009). Among the hundreds of migratory bird species, the European bee-eateris avery commonmigrant during both spring and autumn migration but is especially numerous in April. Its abundance peak coincides with the peak of pollination for the spring and summer crops (e.g. sunflower seeds, onion, garlic, melon, watermelon, pumpkin) and it is accused of being a serious pest problem to the local honey bee populations imported for the purpose of pollinating (Yosef, 2004; Yosef, et al., 2006). Bee-eaters migrate in large flocks between breeding and wintering grounds in a fairly short period of time, during which the high energetic cost of flight combined with a fast metabolism generates a high food demand. Thus, the presence of migratory bee-eaters at stopover sites should be a factor that greatly influences honey bee activity and their populations and diminish honey production and other bee services. In the study, the effectiveness of practices implemented to mitigate conflicts between beekeepers, farmers and migrating birds is also assessed.

\section{MATERIAL AND METHODS}

\section{Bee-eaters effect on bee hives weight gain}

The weight gains of honey bee hives were recorded in 2010 in two kibbutzim: Yotvata $\left(29^{\circ} 53^{\prime} \mathrm{N}, 35^{\circ} 03^{\prime} \mathrm{E}\right)$ and Grofit (29 $56^{\prime} \mathrm{N}$, $35^{\circ} \mathrm{O}^{\prime} \mathrm{E}$ ). Altogether, forty standard wooden hives of the modern Langstroth type, grouped by 4-6 per field, were set up on plantations of sunflowers (Helianthus annuus), onions (Allium cepa) and watermelons (Citrullus lanatus) in mid-March and removed in the last week of April. This six-week period covered the whole pollinating season in those fields. Twenty of these hives (13 in Yotvata and 7 in Grofit) were left unprotected, and in the front and on both sides of the remaining twenty hives (15 in Yotvata and 5 in Grofit) mist-nets commonly used in trapping 
birds in ornithological studies were set up in the first week of April at the time of arrival of migrating flocks of birds, mainly European beeeaters.

Trapping occurred from $07.00 \mathrm{~h}$ till bee-eaters ceased foraging activity on a given day. In order to prevent a return to the study area, all trapped bee-eaters were released at a distance of a minimum of 35 kilometres from the site in the direction of their migration, i.e., to the north (Yosef 2004; Yosef et al., 2006). All the bee hives were weighed at the moment of their placing and then their removal from the fields. Total weight gain of the hives was used as a proxy for a colony's performance, i.e. production of bees and bee products, mainly honey.

\section{Bird fatalities}

Even though mist netting is widely used for ornithological and mitigation programs (Karr, 1981), it poses some injury and mortality risk to the animals caught (Spotswood et al., 2012). Bird fatalities were recorded during a program of bee-eater mitigation and removal from agricultural areas initiated in order to prevent farmers obtaining permits to mass-kill the migrants as "agricultural pests". The study was conducted in spring from 2002 to 2009 in several kibbutzim in southern Israel. The number of bee-hives set up by farmers for pollination ranged from six to eleven per field depending on the size of the field and intensity of pollination required. Six-meter mist-nets were set up in front and on both sides of the hives that were always placed in clumps, and several centimetres off the ground on wooden slats. The distance between nets and hives was set after several trials since birds were able to get around the net walls mounted even as close as $2.5 \mathrm{~m}$ to the hive entrance. Trapping occurred from $07.00 \mathrm{~h}$ till bee-eaters ceased foraging activity (average $4.8 \pm 2.1$ h/day, $\mathrm{N}=625$ days). All bee-eaters were removed from the mist-nets at the earliest. During this eight-year study 395 European bee-eaters were found dead. Postmortem studies were conducted to check for bee stings. Among them 191 birds were studied in detail, not only for number but also for the distribution of stings on the birds' body.

Apart from bee-eaters, other bird species were also mistnetted. The proportion of stung bee-eaters in relation to the entire bird community caught in the mist nets was compared. This allowed for a test of whether honey bees recognize their true predators, the bee-eaters, and if they were selectively stung relatively more often than other species.

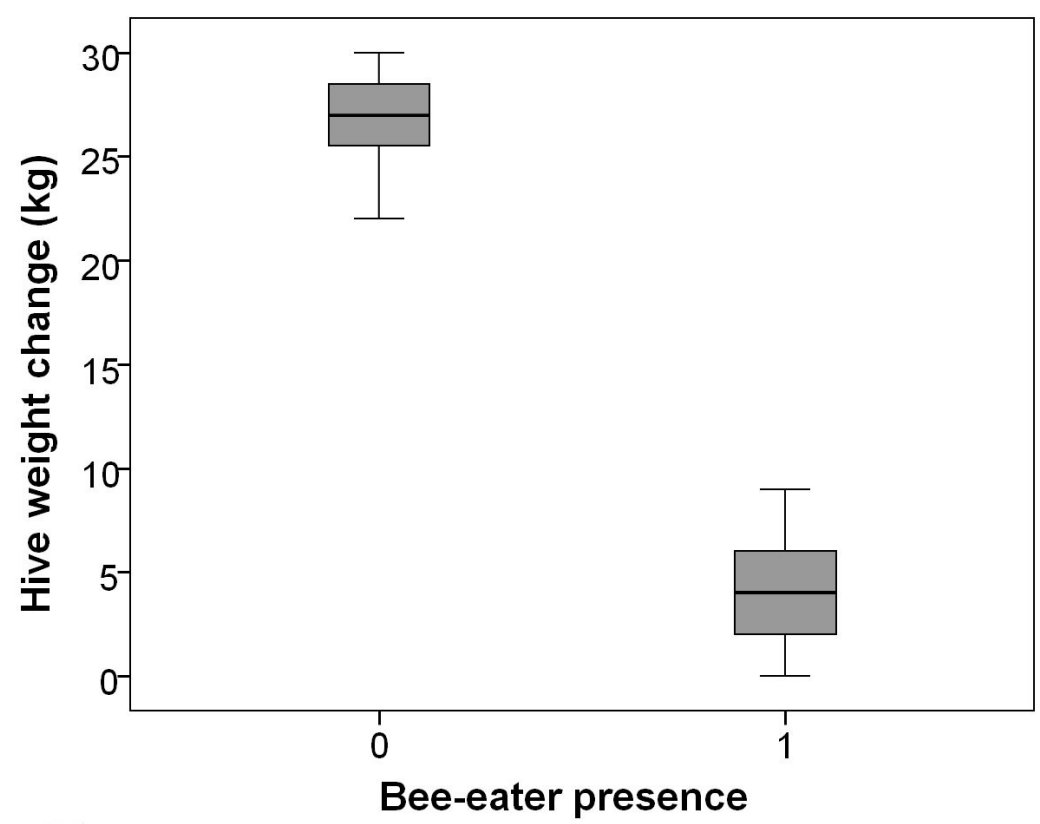

Fig. 1. Weight gains (mean \pm sd and $99 \%$ confidence intervals) of honey bee hives protected (0) and unprotected (1) by mist nets during intensive spring migration of European bee-eaters throughout the Arava Valley, Israel. 
Table 1.

Birds (species and numbers) mist-netted in front of honey bee hives in the Arava Valley, Israel, 2002-2009

\begin{tabular}{|c|c|c|}
\hline Species scientific name & $\mathrm{N}$ & $\%$ \\
\hline Merops apiaster & 8495 & 90.36 \\
\hline Pycnonotus xanthopygus & 173 & 1.84 \\
\hline Streptopelia senegalensis & 117 & 1.24 \\
\hline Sylvia atricapilla & 93 & 0.99 \\
\hline Merops superciliosus & 85 & 0.90 \\
\hline Sylvia curruca & 84 & 0.89 \\
\hline Lanius nubicus & 79 & 0.84 \\
\hline Merops orientalis & 64 & 0.68 \\
\hline Sylvia communis & 42 & 0.45 \\
\hline Phoenicurus phoenicurus & 41 & 0.44 \\
\hline Streptopelia decaocto & 34 & 0.36 \\
\hline Cercotrichas galactotes & 26 & 0.28 \\
\hline Hirundo daurica & 19 & 0.20 \\
\hline Lanius collurio & 16 & 0.17 \\
\hline Sylvia nisoria & 11 & 0.12 \\
\hline Accipiter brevipes & 8 & 0.09 \\
\hline Galerida cristata & 6 & 0.06 \\
\hline Accipiter nisus & 3 & 0.03 \\
\hline Upupa epops & 3 & 0.03 \\
\hline Lanius senator & 2 & 0.02 \\
\hline Total & 9401 & \\
\hline
\end{tabular}

\section{Data analysis}

T-test was used to compare initial weight as well as weight gain of hives protected and unprotected by mist nets. A chi-square test was used to determine if European bee-eaters were attacked by honey bees more frequently than other Merops and avian species, and what body parts were targeted most frequently. $P<0.05$ was chosen as the level of statistical significance. All analyses were performed in SPSS 19.0.

\section{RESULTS}

\section{Hive weight gains}

The initial weight of hives protected and unprotected by mist nets did not differ (mean \pm sd; $40.6 \pm 1.2 \mathrm{~kg}$ versus $40.6 \pm 1.0 \mathrm{~kg}$, respectively, t-test, $\mathrm{t}=0.0, \mathrm{df}=38, \mathrm{p}=1.0$ ). However, changes in hive weight gains differed significantly between the two groups (Fig. 1). The weight gains of bee hives during the spring 
migration of bee-eaters protected by mist nets ranged from 18 to $30 \mathrm{~kg}$ and were on average 6.44 times higher than that of unprotected hives which gained 0-9 $\mathrm{kg}$ (mean $\pm \mathrm{sd}$; $26.4 \pm 3.0 \mathrm{~kg}$ versus $4.1 \pm 2.5 \mathrm{~kg}$, respectively; t-test, $t=25.6, d=38, p<0.001$ ).

\section{Bird fatalities}

Besides 8495 European bee-eaters, 906 individuals of nineteen other bird species were also caught during the study (Tab. 1). Only European bee-eaters were attacked and found dead as a result of bee stings $(395,4.6 \%)$. None of the other bird species were stung $\left(\chi^{2}=40.8\right.$, $\mathrm{df}=1$, p 00.001). Interestingly, other bee-eater species - 85 of Merops superciliosus and 64 of $M$. orientalis - were caught but none were stung $\left(\chi^{2}=5.9, d f=1, p=0.015\right)$. Stings were distributed mostly in the most vulnerable parts of birds' bodies (see Supplementary material).

\section{DISCUSSION}

\section{Are bee-eaters real agricultural pests?}

The weight gain of unprotected honey bee hives at the time of bee-eater migration were drastically lower than that of the hives that were protected by mist nets. These differences cannot be explained by weather or by changes in plant phenology, since they were constant. Hence, it has to be concluded that migrating flocks of bee-eaters significantly affect honey, and probably also brood, production that partially contributes to colony weight gains in the season.

Bee-eaters can affect honey bee productivity in a variety of ways. The evidence most commonly used by apiarists is that bee-eaters readily consume bees. Apiaries attract the bee-eaters that appear even a day after the hives are established (Bellis \& Profke, 2003). The intensive predatory pressure of bee-eaters may significantly reduce the numbers of foraging bees (e.g. Galeotti \& Inglisa, 2001). However, in Europe bee-eaters are thought to be only a seasonal problem and only at their nesting sites (e.g. Chirosa \& Orantes, 2003). Similarly, the little bee-eater M. pusillus is perceived by local hive owners in Ethiopia as the main pest of their bees (Belina et al., 2016) even though the species is a solitary nester. The seasonal but very strong pressure can also be expected from bird flocks migrating in the spring and autumn. The study sites for the current paper are the green areas in the desert that birds use as stopover sites at the northern extremities of a desert crossing (Sahel, Sahara, Sinai) during their spring migration. In order to rebuild their energy reserves they take advantage of the many hives placed in those human-developed oases.

The activity of thousands of birds in the vicinity of honey bee colonies may not only reduce the numbers of foragers that are preyed upon but may also confine the bees to the hives. Bees learn the predation risk and they may reduce their foraging activity to avoid the danger (Fry, 1983). Galeotti \& Iglisa (2001) reported that honey bees reduced their activity in the presence of bee-eaters and even attacked flying bee-eaters. Drastically lowered bee departure rate from the hives can also be observed in Southern Israel at the time of the spring passage of the bee-eater flocks (our unpublished data and beekeepers reports). Reduced bee flight activity, seemingly adaptive in a short-time perspective, is not necessarily advantageous if bee confinement is extensive (Galeotti \& Inglisa, 2001). First, bees are disadvantaged in that they do not gather nectar/pollen. This directly affects beekeeping economics because of reduced amounts of honey available for harvesting. The colony's food reserves may also be critically affected because if food resources are reduced, bees may reduce or stop reproducing and thus weakening the colony. Second, bees crowding in the hive may raise the temperature over the critical level resulting in mass mortality. Also, when the constant nectar flow into the hive is withheld, bees are without a water source needed to maintain a low internal temperature (Lindauer, 1955). This affects the brood already present in the colony and may cause the death of the queen. Another potential damage to apiculture is that bee-eaters indiscriminately prey on bee queens and drones during their mating flights 
(e.g. Galeotti \& Inglisa, 2001; AL-Samie, Ali, \& Taha, 2012). In addition to the direct damage to apiculture, heavy predation by bee-eaters could influence the pollination services that honey bees provide to the farmers.

\section{Mist netting is efficient but possesses risk to birds \\ Distant release of trapped bee-eaters promotes honey bee colonies}

There are several studies that report the use of different methods of eliminating bee-eaters from apiaries. Attempting to scare away the birds with noise, plastic owls and falcons, scarecrows, human vocalizations, distress calls of bee-eaters and coloured streamers all appeared to be inefficient (Tutkun, 1982; Mishra \& Kaushik, 1993; Yosef, 2004). Other studies have also assessed the usefulness of different apiary covers or enclosures including nets (Ali, 2012) but did not report the fate of the birds trapped and the long-term effectiveness of these methods. High weight gains of hives in the current study proved that placing mist nets in the front and on both sides of bee hive was very effective in protection from migrating beeeaters, provided that the caught birds are then released at distances such that it is energeticalIy not in their interests to return to the trapping site (Yosef, 2004).

\section{Bees recognize and attack most vulnerable parts of bee-eaters}

The presented findings show that bees are capable of distinguishing between their foremost predator and other similar species because only European bee-eaters were stung despite several other bird species being caught. Bee-eaters are distinctively colored and possess patterns visible in UV (e.g. Siefferman, 2007). The abundance of bee-eater flocks at the vicinity of hives results in bees frequently encountering the predator and they may acquire their pattern possibly at every trip out of the hive.

The bees may also recognize the genuine enemy from others present just in front of the hives using olfactory cues (Robertson \& Wanner, 2006). They could derive signal(s) from the predator itself or perceive the remains of bee alarm pheromones present on its body. Pheromonal traits could be left while the bee-eater removed the sting apparatus from its previous bee prey before ingestion since the base of the beak, besides the eyes, was attacked more frequently than other body parts. Moreover, since bee-eaters often swallow bees without removing the stings, possible venom residues are present in their bodies (Gulbahar et al., 2003) and mark them in a manner similar to a sting in a wound.

The striking difference between hive weight gains obtained in our study in the presence and absence of bee-eaters can be attributed to their predatory behaviour. Bee queen and drone losses due to bee-eater predation could be widely reduced if queen production and insemination were performed far from bee-eater aggregations and only laying queens were introduced into production colonies. However, even if queen or drone predation by bee-eaters were eliminated, the problem of lowered honey gains would persist. This will provoke heavy conflicts not only between the birds and the apiarists but also with the farming community which relies on the ecosystem services provided by the bees in the form of crop pollination. Official and many more unofficial sources reveal that a common solution to the problem posed by the bee-eaters is their massive extermination. Mist netting followed by the distant-release of migrating bee-eaters has proven to be highly effective but also resulted in some bird losses.

Even though bird mortality seems to be unavoidable, the cost:benefit ratio must be taken into account in contrast to that of unrestrained and uncontrolled mortality at the hands of the apiarists and farmers. Therefore, the benefits of the method of mist-netting outweigh the risk to the individual bird in particular and to the bee-eater migratory populations in general. However, the method should be recommended only in regions of bird migration and where honey bee services expected from apiarists include not only bee products but also agricultural pollination. Otherwise, placing the hives away from breeding places and known migratory routes of 


\section{Ј. APIC. SCL. VUL. Fi NO. 12018}

bee-eaters, removing all bird perches available in the vicinity, temporarily moving bee colonies or even appropriate crop planning are recommended in order to avoid the conflict between humans and bee-eaters.

\section{ACKNOWLEDGEMENTS}

We thank Ron Poraz of Moshav Ein Yahav for help with weighing his bee-hives, and the farmers at Kibbutz Grofit and Yotvata for allowing us to work in their fields. Many volunteers and students helped with the monitoring of the nets. The project was conducted under the supervision of the Eilat Branch of the Israel Nature Reserves \& Parks Authority with the aim of reducing the farmer-bee-eater conflict. Authors contributions: RY conducted the study, PT performed statistical analyses, AL wrote the first draft of the manuscript and all authors contributed to revisions.

\section{Supplementary material}

The supplementary material for this manuscript can be found as an attachment.

\section{REFERENCES}

Alfallah, H.M., Alfituri, M., \& Hmuda M. (2010). The impact of bee-eater Merops apiaster on the behavior of honey bee Apis mellifera L. during foraging. Journal of Plant Protection and Pathology, Mansoura University, 7, 1023-1034.

Al-Ghzawi, A.A.A., Zaitoun, S.T., \& Shannag, H.K. (2009). Incidence and geographical distribution of honeybee (Apis mellifera L.) pests in Jordan. Annales de la Société Entomologique de France (N.S.), 45, 305-308. http://dx.doi.org/10.1080/00379271.20 09.10697615

Ali, M.A. (2012). Definition, survey, monitoring and efficiency of directions of bird-trapping nets for trapping the bee-eating birds (Merops: Meropidae) attacking honey bee colonies. International Journal of Scientific and Engineering Research, 3(1), 1-8.

AL-Samie, M.A., Ali, M., \& Taha, E.L.-K.A. (2012). Beeeating birds (Coraciiformes: Meropidae) reduce virgin honey bee queen survival during mating flights and foraging activity of honey bees (Apis mellifera L.). International Journal of Scientific and Engineering Research, 3(6), 1-8.

Belina, D., Daba, T., Eshetu, A., \& Giro, B. (2016). Identification of major honeybee pests and predators' and associated risk factors: Emphasis to bee-eater birds (Meropidae) in west Shewa zone of Oromia regional state, Ethiopia. Livestock Research for Rural Development, 28, Article \#217.

Bellis, G.A., \& Profke, A.M. (2003). Rainbow beeeaters (Merops ornatus) as a monitoring tool for honeybees (Apis mellifera L.; Hymenoptera: Apidae). Australian Journal of Entomology, 42, 266-270. DOl: 10.1046/j.1440-6055.2003.00356.x

Birdlife International (2016). Merops apiaster. The IUCN Red List of Threatened Species 2016: e.T22683756A86910074. Retrieved September 18, 2017, from http://dx.doi.org/10.2305/IUCN. UK.2016-3.RLTS.T22683756A86910074

Brochet, A.-L., Van Den Bossche, W., Jour, S., Ndang'ang'a, P.K., Jones, V.R., Abdou, W.A.L.I., .. Butchart, S.H.M. (2016). Preliminary assessment of the scope and scale of illegal killing and taking of birds in the Mediterranean. Bird Conservation International, 26, 1-28. DOl: 10.1017/S0959270915000416

Chirosa, M. \& Orantes, F.J. (2003). Estudio de la incidencia del abejaruco (Merops apiaster) en los colmenares de la Comunidad Autónoma andaluza [CD]. Consejería de Medio Ambiente, Junta de Andalucía.

Cramp, S., \& Simmons, K. (1985). Handbook of the Birds of Europe, the Middle East and North Africa: The Birds of the Western Palearctic: Terns to Woodpeckers. Volume 4. Oxford: Oxford University Press.

De Jong, D. (1990). Insects: Hymenoptera (ants, wasps, and bees). In Honey bee pests, predators, and diseases. (pp. 135-155). Ithaca, New York, USA: Cornell University Press.

Dhindsa, M.S., \& Saini, H.K. (1994). Agricultural ornithology: an Indian perspective. Journal of Biosciences, 19, 391-402. DOl: 10.1007/BF02703176 
Dukas, R. (2001). Effects of predation risk on pollinators and plants. In Cognitive ecology of pollination. (pp. 214-236). Cambridge, UK: Cambridge University Press.

El-Sarrag, M.S.A. (1993). Studies of Some Factors Affecting Rearing of Queen Honeybees (Apis me/lifera L.) Under Riyadh Conditions. Agricultural Research Centre, King Saud University, Research Bulletin, 41, 30-41.

Esmaili, M. (1974). Bee-eaters - a problem for beekeepers in Iran. American Bee Journal, 174, 136137.

Fry, C.H. (1 983). Honeybee predation by bee-eaters, with economic considerations. Bee World, 64, 6578.

Fry, C.H., \& Fry, K. (2010). Kingfishers, bee-eaters and rollers. A\&C Black.

Galeotti, P., \& Inglisa, M. (2001). Estimating predation impact on honeybees Apis mellifera L. by European bee-eaters Merops apiaster L. Revue d'Ecologie (la Terre et la Vie), 56, 373-388.

Glaiim, M.K. (2014). Occurrence and status of beeeaters, Merops spp. (Coraciiformes: Meropidae), and their attacks on honey bee colonies in Kerbala Province, Iraq. Journal of Apicultural Research, 53, 478488. http://dx.doi.org/10.3896/IBRA.1.53.4.04

Goulson, D., Nicholls, E., Botías, C., \& Rotheray, E.L. (2015). Bee declines driven by combined stress from parasites, pesticides, and lack of flowers. Science, 347, 1435-1445. DOl: 10.1126/science.1255957

Gulbahar, O., Mete, N., Ardeniz, O., Onbasi, K., Kokuludag, A., Sin, A., Sebik, F. (2003). Laryngeal edema due to European bee-eater (Merops apiaster) in a patient allergic to honeybee. Allergy, 58, 453. DOl: 10.1034/j.1 398-9995.2003.00125.x

Gyurácz, J., Nagy, K., Fuisz, T.l., Karcza, Z., Szép, T. (2013). European Bee-eater (Merops apiaster Linnaeus, 1758) in Hungary: a review. Ornis Hungarica,
27(2), 1-22. https://doi.org/10.2478/orhu-20140001

Hussein, M.H. (2000). Beekeeping in Africa. I - North, East, North-East and West African Countries. Apiacta, 7, 32-48.

Hussein, M.H., Rateb, S.H., Ali, A.M., \& Morsi, M.A. (2001). Seasonal activity of some predators of honeybee colonies in Assiut region, Egypt. In Proceedings of 7 st Conference on Safe Alternative Pesticides for Pest Management (329-348). Assiut University, Egypt.

Karr, J.R. (1981). Assessment of biotic integrity using fish communities. Fisheries, 6, 21-27. http://dx.doi. org/10.1577/1548-8446(1981)006<0021:AOBIU $F>2.0, C 0 ; 2$

Lindauer, M. (1955). The water economy and temperature regulation of the honeybee colony. Bee World, 36, 62-111.

Martínez, C. (1984). Notes on the prey taken by beeeaters Merops apiaster at a colony in central Spain. Alauda, 52, 45-50.

Mishra, R.C., \& Kaushik, H.D. (1993). Green bee-eater, Merops orientalis and evaluation of possible methods to reduce honeybee predation. Pavo, 31, 113 116.

Moran, S., \& Keidar, H. (1993). Checklist of vertebrate damage to agriculture in Israel. Crop Protection, 12, 173-182. https://doi.org/10.1016/02612194(93)90105-R

Potts, S.G., Biesmeijer, J.C., Kremen, C., Neumann, P., Schweiger, O., Kunin, W.E. (2010). Global pollinator declines: trends, impacts and drivers. Trends in Ecology and Evolution, 25, 345-353. https://doi. org/10.1016/j.tree.2010.01.007

Ranabhat, N.B., \& Tamrakar, A.S. (2009). Natural enemies of honey bees Apis cerana F and associated problems in beekeeping in Kaski, W Nepal. Journal of Natural History Museum, 24, 89-95. 
Robertson, H.M., \& Wanner, K.W. (2006). The chemoreceptor superfamily in the honey bee, Apis mellifera: Expansion of the odorant, but not gustatory, receptor family. Genome Research, 16, 1395-1403. DOl: $10.1101 /$ gr.5057506

Robinson, W.S. (1981). Beekeeping in Jordan. Bee World, 52, 57-67.

Siefferman, L., Wang, Y.-J., Wang, Y.-P., \& Yuan, H.W. (2007). Sexual dichromatism, dimorphism, and condition dependent coloration in blue-tailed bee-eaters. Condor, 109, 577-584.

Spotswood, E.N., Roesch Goodman, K., Carlisle, J., Cormier, R.L., Humple, D.L., Rousseau, I., ... Barton, G.G. (2012). How safe is mist netting? evaluating the risk of injury and mortality to birds. Methods in Ecology and Evolution, 3, 29-38. DOl: 10.1111/j.2041210X.201 1.00123.x

Tucker, G.M. \& Heath, M.F. (1994). Birds in Europe: their conservation status. Cambridge, U.K.

Tutkun, E. (1 982). Research on the definition, distribution, bioecology, economic importance and a new control method of Merops apiaster, harmful to honeybees in Central Anatolia. Bitki-Koruma-Bulteni, 22, 148-159.
Yirga, G., Koru, B., Kidane, D., \& Mebrahatu, A. (2012). Assessment of beekeeping practices in Asgede Tsimbla district, Northern Ethiopia: Absconding, bee forage and bee pests. African Journal of Agricultural Research, 7, 1-5. DOI: 10.5897/AJAR10.1071

Yosef, R. (2004). Resolving the apiculture and migratory bee-eater (Merops apiaster) conflict in the Arava valley, Israel. In Advances in Vertebrate Pest Management, Vol. III. (pp. 117-122). Filander Verlag.

Yosef, R., \& Markovets, M. (2009). Spring bird migration phenology in Eilat, Israel. Zookeys, 37, 193-210. DOl: 10.3897/zookeys.31.107

Yosef, R., Markovets, M., Mitchell, L., \& Tryjanowski, P. (2006). Body condition as a determinant for stopover in Bee-eaters on spring migration in the Arava Valley, southern Israel. Journal of Arid Environments, 62, 401-411. https://doi.org/10.1016/j. jaridenv.2005.06.012 
Supplementary information on bird fatalities: sting location

\section{Methods}

Data were collected incidentally during the program of bee-eater mitigation initiated in order to reduce conflicts between the migrants and beekeepers and farmers. Some fatalities of mist-netted birds were recorded from bee stings. Based on the body topography of the beeeaters, sting locations were classified as follows: (1) the eyes - both left and right together, (2) unfeathered body parts (skin around eyes, legs, base of beak), and (3) feathered areas (crown, nape, chin, back, ventral region). The proportion of the above classes were used to test the proportion of stings found in the particular body regions of the bee-eater.

Both eyes covered proportionally $0.21 \%$ of the whole body, un-feathered parts 3.80\% (skin around eyes $0.45 \%$, base of beak $0.37 \%$, legs $2.98 \%$ ), and the rest $95.99 \%$ of the body was feathered (crown 6.72\%, nape $2.24 \%$, chin $2.24 \%$, back $28.36 \%$, ventral region $35.82 \%$, wings $17.91 \%$, rest of body $2.7 \%$ ). The proportion of the above classes of body parts available was established by analysis of pictures of bee-eaters using the AxioVision 4.8, Carl Zeiss software.

\section{Results}

It took as little as two stings in the eyes to cause the death of a bee-eater (only 3 among 191 $(0.016 \%)$ birds studied in detail for distribution of stings). However, the mean number of stings found on bee-eaters was $11.2 \pm 8.2$ (median $=9$; range $2-66, \mathrm{~N}=2950$ stings).

The body part of the bee-eater that was most often stung by bees were the eyes (1546 stings versus 6 expected assuming a random distribution on the body) and non-feathered parts including skin around eyes and beak base (788 stings versus 112 expected). Feathered body parts were attacked by bees significantly less often than expected by chance (616 stings versus 2832 expected) $\left(\chi^{2}=3460, \mathrm{df}=2, p<0.001\right.$; Supplementary Fig. 1).

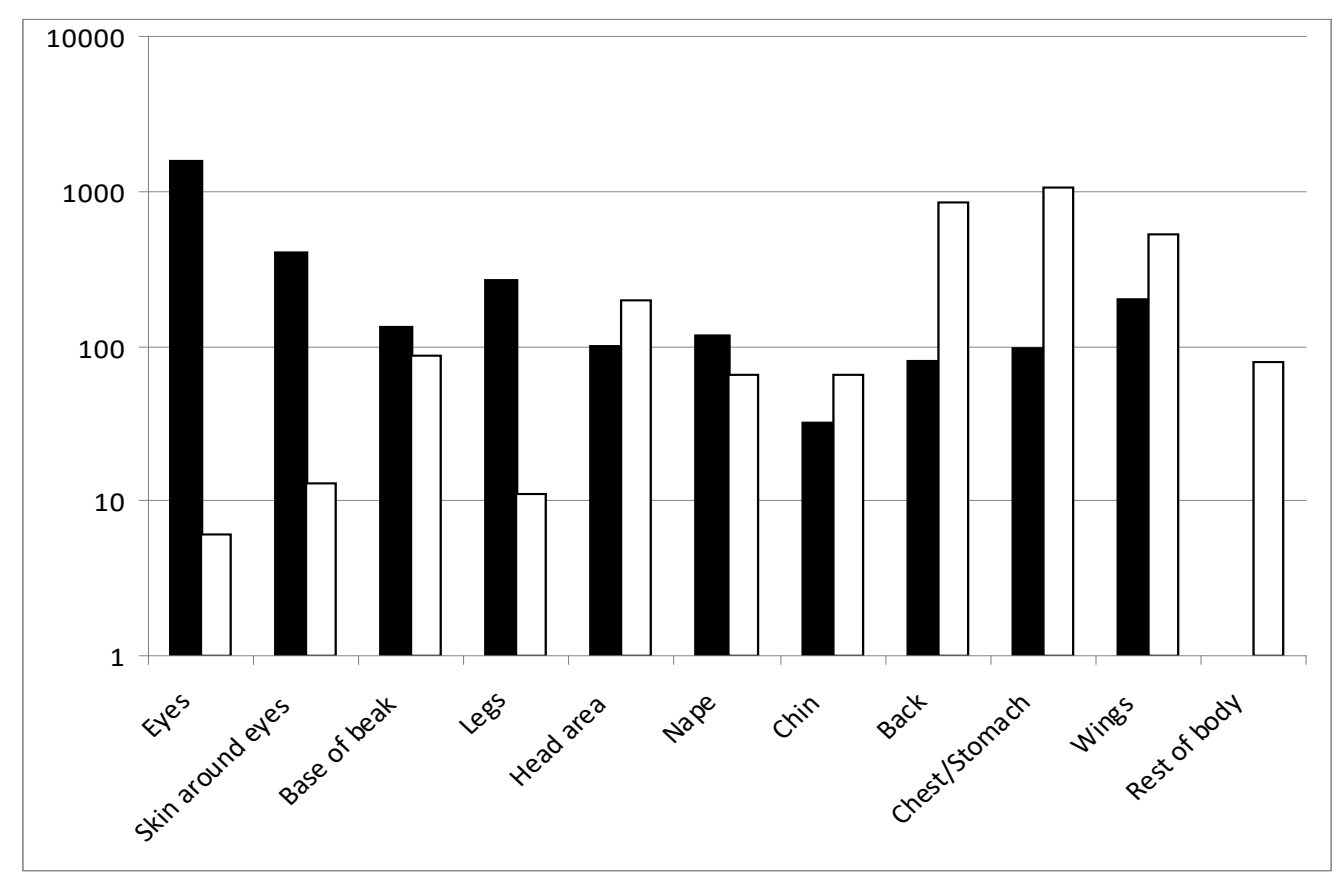

Supplementary Fig. 1 Distribution of 2950 bee stings ( $Y$ axis) on the bodies ( $X$ axis) of 191 European Beeeaters, 2002-2009

Data are presented on logarithmic scale, black columns - observed, white columns - expected values. 


\section{Discussion}

Not only is detection of the predator by the honeybee selectively advantageous, but also the distribution of stings on the body is non-random. The eye is a well-known target for vertebrate prey when being handled by predators and is considered to be one of the reasons why the eyes of many predators are camouflaged by an eye-mask or a black stripe (e.g. Bortolotti, 2006; Negro et al., 2007). Obviously plumage partially trammels the sting. Still however, targeting the eyes of birds may be an extraordinarily efficient tactic, since bee-eaters seem to be immune to ingested bee venom (Cramp \& Simmons, 1985). Moreover, our findings suggest that these birds may die from just two stings placed within the eye orbit. European honey bees, due to a high risk of death after stinging, are not inclined to sting and preferably use other behavioral patterns out of their defensive repertoire (Cunard \& Breed, 1998). Similarly, giant honey bee Apis dorsata colonies mass release guards to pursue raiding blue-bearded bee-eaters Nyctyornis athertoni (Kasberger \& Sharma, 2000). However, birds caught in mist-nets were exposed at the front of bee hives. Continuous stinging was most probably the result of the fact that the bees may not have recognized that the bird was already badly stung or dead, because metabolic processes are functional for a longer period of time. With the help of venom pheromones, the sting apparatus left in the victim promotes additional stinging by other bees at the same location of the body and explains the clustered pattern of sting distribution.

\section{REFERENCES}

Bortolotti, G.R. (2006). Natural selection and avian coloration: protection, concealment, advertisement or deception? In Bird Coloration. Volume 2: Function and Evolution (pp. 3-35) Cambridge: Harvard University Press.

Cramp, S., \& Simmons, K. (1985). Handbook of the Birds of Europe, the Middle East and North Africa: The Birds of the Western Palearctic: Terns to Woodpeckers. Volume 4. Oxford, Oxford University Press.
Cunard, S.J., \& Breed, M.D. (1998). Post-stinging behavior of worker honey bees (Hymenoptera: Apidae). Annals of the Entomological Society of America, 97, 754-757. https://doi.org/10.1093/aesa/91.5.754

Kastberger, G., \& Sharma, D.K. (2000). The predatorprey interaction between blue-bearded bee eaters (Nyctyornis athertoni Jardine and Selby 1830) and giant honeybees (Apis dorsata Fabricius 1798). Apidologie, 37, 727-736. https://doi.org/10.1051/ apido:2000157

Negro, J.ı, Bortolotti, G.R., \& Sarasola, J.H. (2007). Deceptive plumage signals in birds: manipulation of predators or prey? Biological Journal of the Linnean Society, 90, 467-477.

Yosef, R., Zduniak, P., \& Tryjanowski, P. (2012). Unmasking Zorro: functional importance of the facial mask. Behavioral Ecology, 23, 615-618. https://doi. org/10.1093/beheco/ars005 
